\title{
Old but Gold: The Use of Picture Cues to Teach Writing (An Experimental Research)
}

\author{
${ }^{1}$ Soviyah, ${ }^{2}$ Yunia Purwaningtias \\ English Education Department, Universitas Ahmad Dahlan \\ ${ }^{1}$ soviyah@pbi.uad.ac.id, ${ }^{2}$ yuniatias@gmail.com
}

\begin{abstract}
Picture use in an educational setting fits the idiom: old but gold. They have been used in the classrooms of various levels across generations. They are long known and proved to have the ability to help motivate, demonstrate, and instruct the students during a learning process. However, still, there are plenty of studies done revealing how successfully pictures work in theclassrooms up today. This study is a sort of complement to the phenomenon as it focuses on researching the use of pictures in a classroom. Specifically it aims at finding out the effectiveness of the use of picture cues in teaching writing. The study belongs to an experimental research involving two groups of experiment and control. The eighth grade students of a private junior high school in Central Java Indonesia are chosen as the subject of the research during 2017/2018 academic year. Employing sample population technique, the study involves a total number of 56 students who are equally divided into 28 students as the experimental group and 28 students as the control group. The experimental group is taught using picture cues while the control group is taught without picture cues. Pre-test and post-test are used as techniques to collect the data. As for the data analysis technique, it's done quantitatively applying both descriptive and inferential statistics. The result of the research shows that there is significant difference in the students' writing ability between those taught using picture cues and those who are not. This can be seen from the difference in the mean score between them. The result of the pretest shows that at the beginning, both experimental and control groups have slightly different ability in writing with the mean scores 51.32 and 47.86 respectively. Meanwhile, the result of the posttest indicates an obvious difference between them in which the experimental group gains 65.75 as its mean score and the control group gets 59.14. Furthermore, the application of Independent t-test calculation results in the score of 0.000 , which is lower than 0.05 . This means that the use of picture cues is effective. Based on these results, it can be concluded that the use of picture cues is effective to teach writing to students.
\end{abstract}

Key words: picture cues, writing, experimental research, recount text

How to Cite: Soviyah.,Purwaningtias, Y.(2018). Old but Gold: The Use of Picture Cues to Teach Writing

(An Experimental Research).English Language Teaching Educational Journal, 1(1), 38-48.

\section{INTRODUCTION}

In Indonesia, English serves its position as a foreign language and becomes a compulsory subject from secondary school to college level. In elementary school level, English is categorized into one of the extra-curricular subjects, and hence it is optional. In the secondary school level, the learning of English has a purpose that the students of secondary school are able to improve their mastery of the four language skills, i.e. listening, speaking, reading, and writing. Besides, the students are also hoped to have a good mastery on English 
micro skills such as vocabulary, pronunciation, structure, and grammar. Specifically in junior high school level, the target of English learning is to make the students be competent speakers of English, in both spoken and written forms. In other words, it can be said that on completing their three year school schema, the students of junior high school are expected to be able to demonstrate competency in the four skills of English i.e. listening, speaking, reading, and writing.

Among four skills of English, writing has been considered the most difficult skill to learn. This is because unlike the other three skills, writing is complicated and requires mastery not only of grammatical and rhetorical devices but also of conceptual and judgmental elements (Heaton, 1975). In addition to being complicated by nature, the process of writing is demanding as well. It is a skill demanding process (Tedrow, 2018). Interestingly, in the classroom context, the strong complaints about the complexity of writing are coming not only from the students, quite often teachers also voice complaints about how difficult to teach writing is by stating that the students just can't write! (Tedrow,2018). This situation slowly but surely has caused either students or teachers have a distaste for writing.

One of the causes of the catastrophe is because both teachers and students have not done enough of writing. On the one hand, the students' writing works they've done has been scrutinized quite long even before they are ready for inspection. On the other hand, though, very little time and support or guidance is provided by the teachers because the teachers are busy with administrative stuff. Practically, much of the writing task is assigned, and then graded, with an eye to finding mistakes and shortcomings. With such a condition, after many mistakes they make along the writing process, students will equate writing with spelling and grammar business rather than finding a voice and space for selfexpression. However in fact, like sports, writing is a skill that requires hours of practice, guidance, and feedback for successful improvement. But like a sports game too, teachers often put the students in a repeated and similar classroom routine in which they give them directions (a writing formula to follow), a topic the students can't choose (the writing assignment), and a sports game style writing situation (a grade for a writing course or a standardized writing test). Consequently, neither such a situation makes the students and the teachers feel that both of them are either good writing teachers or good writers.

The portrayed description above is exactly what the English teacher explained during the interview, which marked the beginning of the research. The research started with an intensive preliminary interview with the English teacher and the students of the school in which the research was done. From the interview it was revealed that there were some problems faced by the students when it came to the writing class. To sum up, these problems covered the students' motivation in writing which was quite low, the students' interest in writing which was regarded inadequate, the students' difficulty in expressing their ideas, the presence of writer's block phenomenon, the monotonous learning activities, and the dependency on one single English textbook. Furthermore, it was also found out that the teacher rarely used media during her 
teaching. The activities of writing class were mainly based on the textbook. All these problems were assumed to have caused the students to get bored easily during the lesson and show constant laziness to do the homework. As a result, the students could not show competence in writing yet. This could be seen from the students' writing works which displayed some writing drawbacks such as many grammatical errors, limited vocabulary use, and lack of coherence and unity. With these existing problems, the writing class surely needs help and calls for immediate solution.

One of the ways to solve the problems is by utilizing learning media, especially the media that best fits the situation explained previously. And it's picture cues. Why picture cues? There are some reasons for this. Firstly, picture cues are interesting as they contain various images. Moreover as these images are presented in series, they are able to encourage and stimulate the students in composing a text. Secondly, picture cues make creative students. As picture cues have a realistic format that helps the students to think and get more ideas in writing, they will definitely make students to be creative writers. Furthermore, pictures cues can stimulate language learning process because the pictures they provide usually contain cultural information. In addition, just a cherry at the top of the cake, picture cues are easy to make and inexpensive, it's only needed pictures from any available sources such as used magazines, newspaper, and internet. These reasons are the center onto which the topic of this study is headed i.e. to have a trial on the use of picture cues in teaching writing and finding out its effectiveness.

\section{PICTURE CUES}

Literally, Picture cues is a word which is made up of two sequential words combined together i.e. picture and cue. The word picture is defined as a visual representation of something, such as a person or scene, produced on a surface, as in a photograph, painting, etc (Collins, 2005). In a similar but simpler way, Oxford dictionary (2015) gave definition of picture as a painting or drawing, etc that shows a scene, a person, or a thing. Meanwhile, cue is referred to an action or event that is a signal for somebody to do something (Oxford, 2015). More specifically, Collins (2005) specified cue as the part, function, or action assigned to or expected of a person. Combining these given meanings, picture cues can be defined as visual representation of something (a person, a scene, or a thing) produced on a surface which contain signals for somebody to do something. More briefly, picture cues can be referred to a number of pictures that contain sequences of signals or events which are related each other.

In the language learning field, the role of pictures is noticeably significant. Pictures are usually used as learning media function to support and give help to the process of teaching and learning. It's because pictures can not only motivate but also demonstrate and instruct the students during a learning process (Wright, 1989). By nature, as pictures are interesting to see, they are able to attract students so the students are more motivated to learn further. In addition, pictures are stimulating as well, as they can provide cultural information 
through images. In sum, pictures have characteristics which can stimulate the language learning process, and thus they are beneficial to use.

Taking a focused scope on the process of learning writing, the roles pictures and picture cues play are generally the same. In details, the functions of pictures cues are listed below:

1. Motivate students in learning writing. Pictures cues can increase students' motivation because it can make the situation of the classroom more interesting.

2. Inform students about the object. Picture cues can provide information including objects, actions, events, and relationships.

3. Train students to arrange the plot story. Picture cues can help students to arrange the story plot because picture cues provide sequences of events which interconnected one another. This way, the students will be able to arrange the story plot more easily.

4. Facilitate students to expand the story. Since picture cues usually show objects, actions and even relationship, they can provide cue answer substitutions and sentence completions. Under this function, students will be able to start their written composition more easily and quickly.

Typically, there are three kinds of picture cues (Brown, 2004), they are:

1. Short sentence; containing a drawing of some simple actions, and the testtakers are to write brief sentences.

Test-takers see the following picture

1.

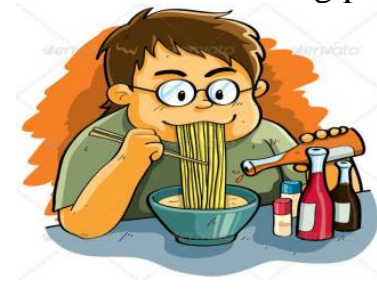

2.

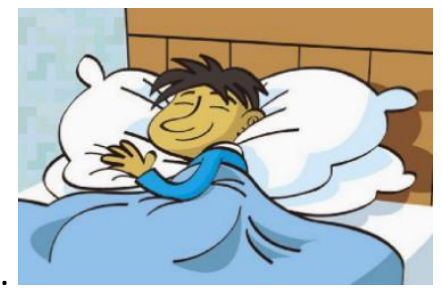

Test-takers read:

1. What is the man doing in 1st picture?

2. What is the man doing in 2nd picture?

Test-takers write:

1. He is eating, he is eating his lunch, he is holding the spoon etc.

2. Picture description; describing something based on the picture. Test-takers are asked to describe the picture using four of the following prepositions: on, over, under, next to, around. As long as the prepositions are used appropriately, the criterion is considered to be met.

3. Picture sequence description; describing story line picture that can provide stimulation to the students and it must be ambiguous picture, because an 
open-ended task at the selective level would give test-takers too many options.

Test-takers see

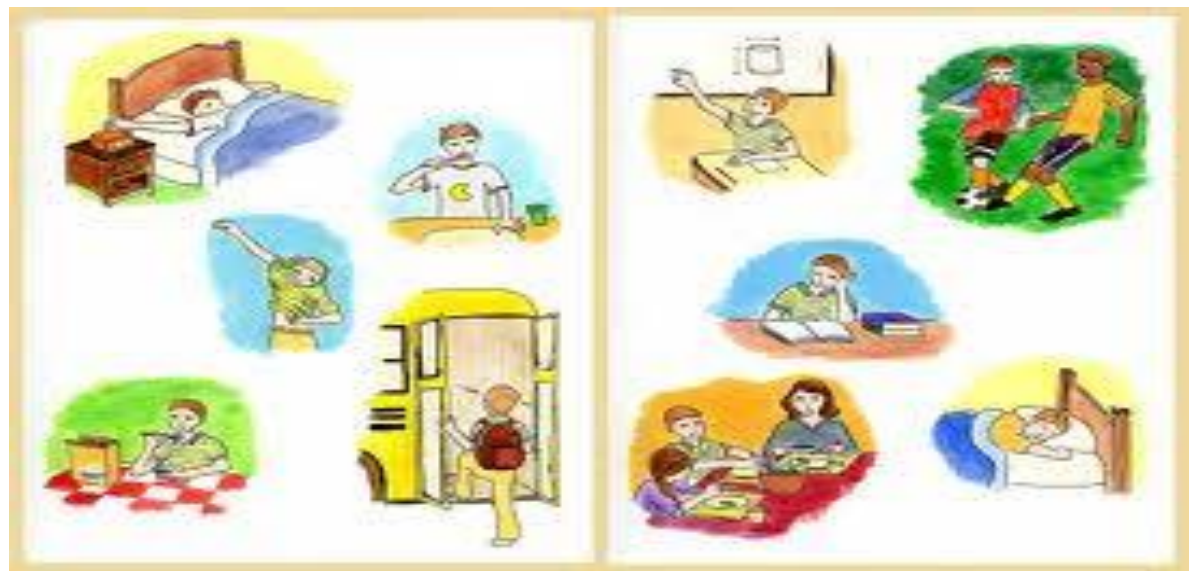

Test-takers read: describe the man's morning routine in six sentences

Test-takers write:

He gets up at five o'clock

He takes a shower at 05.30

At 06.40 he gets dressed

Than he eats breakfast

About 06.30 he leaves the house

Then he plays football in the afternoon.

Completing the functions of picture cues listed previously, Harmer (1998) stated that picture cues have some specific characteristic which cover the followings:

1. Drilling: with lower level students, picture cues help teacher drill or give exercises to the students how to do cueing different sentences and practising vocabulary in the simple sentences.

2. Communication: picture cues are extremely useful for a variety of activities such as describing and drawing activities that have related pictures.

3. Understanding: one of the most appropriate uses of picture cues is for presenting and checking meanings. The pictures should be related and easy to guess.

4. Ornamentation: picture cues have clear extra visual dimension.

5. Prediction: picture cues are useful for getting students into what is coming next. Thus students will look at the pictures and guess what is shown. 
6. Discussion: picture cues can stimulate questions such as "What is showing?"

In using the picture cues, there some suggested procedures. Prior to the use of picture cues in the classroom, the teacher should decide the theme/topic first. To do this step, it's best to refer to the course syllabus. Next, the teacher provides the picture cues. For this stage, the teacher can make the pictures herself, search the internet, or take the pictures from used magazines or newspaper. In the classroom, these are the suggested procedures of using picture cues:

1. The teacher arranges the pictures based on the theme/topic learned.

2. The teacher divides the class into five or six groups, depending on the size of the class.

3. The teacher distributes one set of the picture cues to each group.

4. The teacher asks the students to pay attention to every object shown in the picture, then write it one by one chronologically according to the order of occurrence.

5. On finishing the writing, the students are asked to submit the work to the teacher.

\section{RESEARCH METHOD}

With the aim of finding out the effectiveness of using picture cues to teach writing, this study was categorized into an experimental research. The research was conducted in a private junior high school in Banjarnegara district, Central Java province. The research was done in May 2018 and involved56 students of grade eight. These students were divided into groups of experiment and control consisting of 28 students each. There was no sampling technique used as the population served as the sample as well.

As for the research variables, there were two variables used, i.e. independent variable and dependent variable. In this case, using picture cues to teach writing was the independent variable $(\mathrm{X})$ and students'writing ability was the dependent variable (Y).

A writing test in which the students were asked to write a text was utilized as the technique to collect the research data. Meanwhile, for the data analysis, it was done quantitatively by applying the descriptive and inferential anlysis, while t-test was used as the hypothesis testing method.

\section{Research Procedures}

As previously stated, this study was an experimental research and involved two research groupsnamely experimental and control groups. The two groups were given the same material, which was recount text, but different treatment. The experimental group was taught by using picture cues and the control group was taught without using picture cues.

The picture cues were used as the learning media. For the picture cues, they were made of some series of pictures which were interrelated and having the common thread among them. The theme of the picture cues was centered 
around Holiday. These picture cues were given in meeting 3, 4, and 5 consecutively.

The researcher acted as the teacher. She did the teaching by complying with the lesson plan prepared beforehand. The general teaching procedures were: the researcher explained the material and after that the students of the experimental group were given the picture cues and asked to write a text based on them. On finishing the text, the students submitted their writing works to the researcher. Then, the researcher assessed and gave feedback. Table 1 depicts the detailed schedule of the treatment.

As for the writing test, both groups were given the same pre-test and post-test in which they were asked to write a recount text on their own. To assess the test results, it was used a writing rubric. As the final step, the results of both pre-test and post-test were compared to each other to find out whether or not there was significant difference between them.

Table 1. Schedule of the Treatment

\begin{tabular}{ccl}
\hline Meeting & \multicolumn{1}{c}{ Day } & \multicolumn{1}{c}{ Topic } \\
\hline 1st & $\begin{array}{c}\text { Saturday 5th, } \\
\text { May 2018 }\end{array}$ & $\begin{array}{l}\text { Recount text (function, generic } \\
\text { structure, language use) }\end{array}$ \\
2nd & $\begin{array}{c}\text { Monday 7th, } \\
\text { May 2018 }\end{array}$ & Holiday; Past tense \\
3rd & $\begin{array}{c}\text { Tuesday 8th, } \\
\text { May 2018 }\end{array}$ & $\begin{array}{l}\text { Writing sentences based on the given } \\
\text { picture cues }\end{array}$ \\
& $\begin{array}{l}\text { Wednesday 9th, } \\
\text { May 2018 }\end{array}$ & $\begin{array}{l}\text { Writing recount paragraph based on } \\
\text { the given picture cues }\end{array}$ \\
& Friday 11th, & $\begin{array}{l}\text { Writing recount paragraph based on } \\
\text { the given picture cues }\end{array}$ \\
\hline
\end{tabular}

\section{RESULTS AND DISCUSSION}

Based on the findings and anlysis, it could be concluded that in terms of the writing ability, there was significant differencebetween the experimental group and the control group. It means that there was a difference between the students who were taught using picture cues and without using picture cues. Table 2 below shows the difference between them. 
Table 2. Descriptive Analysis of Pre-test and Post-test of the Experimental and Control Group

\begin{tabular}{|c|c|c|c|c|c|}
\hline \multirow[t]{3}{*}{ Class } & \multirow[t]{3}{*}{ Category } & \multicolumn{4}{|c|}{ Frequency } \\
\hline & & Minimum & Maximum & Mean & St. \\
\hline & & & & & Deviation \\
\hline \multirow[t]{2}{*}{ Experiment } & Pre-test & 28 & 76 & 51.32 & 13.894 \\
\hline & Post-test & 35 & 89 & 65.75 & 15.558 \\
\hline \multirow[t]{2}{*}{ Control } & Pre-test & 34 & 71 & 47.86 & 11.323 \\
\hline & Post-test & 40 & 78 & 59.14 & 12.474 \\
\hline
\end{tabular}

(Source: Data Analysis SPSS 16)

From table 2 of the descriptive analysis of both pre-test and post-test between the experimental and control groups above, it's obvious that there is a difference between the two groups. The difference lays on the aspects of minimum and maximum score, mean, and standard deviation. Seen from these three aspects, it can be said that the experimental group outnumbers the control group. The first aspect is of the minimum and maximum score. In terms of the minimum and maximum score, the experimental group shows an increase from 28 and 76 in the pre-test to 35 and 89 in the post-test. Meanwhile, the control group improves lesser from 34 and 71 in the pre-test to 40 and 78 in the posttest. As for the mean score, the experimental group shows better improvement than that of the control group in which it increases from 51.32 in the pre-test to 65.75 in the post-test, while the control group scores 47.86 in the pre-test to 59.14 in the post-test. Regarding the standard deviation score, again, the experimental group exceeds the control group with 1.664 points (from 13.894 in the pre-test to 15.558) while the control group only gains 1.151 (11.323 in the pre-test to 12.474 in the post-test).

In addition to the descriptive analysis, it's also done the inferential analysis. This analysis is done in order to check whether or not the distribution of the data is normal. In this study, Kolmogorov-Smirnov formula completed with SPSS 16 is utilized as the method to test the data normality. The complete result of the normality test is displayed through table 3 below.

Table 3. Normality Test of the Pre-test and Post-test of the Experimental and Control groups

\begin{tabular}{lllll}
\hline Class & Category & \multicolumn{2}{l}{ Kolmogorov Smirnov } & Decision \\
\cline { 3 - 5 } & & Statistic & Sig. & \\
\hline Experiment & Pre-test & 0.144 & 0.200 & Normal \\
& Post-test & 0.118 & 0.200 & \\
Control & Pre-test & 0.113 & 0.200 & Normal \\
& Post-test & 0.109 & 0.200 & \\
\hline & & & (Source: Data Anaysis SPSS16)
\end{tabular}


Based on the data on table 3 , it can be concluded that both research data of the experimental and control groups are normally distributed. It's because seen from the level of significance 0.05 , both groups show the same result, which is higher than 0.05 . The experimental group reaches the data probability (sig.) of 0.200 in both of its pre-test and post-test, which means that the data distribution of the experimental group is normal. The control group shows the same results as well. It gains 0.200 as its data probability (sig.) in both pre-test and post-test run.

Besides the test of normality, another inferential analysis done is homogeneity test. Homogeneity test is done in order to know whether or not the score of one group has the homogeneous variance with the score of the other group's. In other words, homogeneity test functions to analyze whether the population score is homogenous or not. In this study, the researcher used SPSS 16. In this case, the data is said homogeneous if the probability (sig.) is higher than the obtained probability, which is 0.05 . In contrast, if the probability (sig.) score is lower than the probability score obtained (0.05), the data will be considered not homogeneous. The results of the homogeneity test of this study is illustrated through the following table:

Table 4.Test of Homogeneity

\begin{tabular}{llll}
\hline \multirow{2}{*}{ Class } & \multicolumn{2}{l}{ Levene Statistic } & Decision \\
\cline { 2 - 4 } & Statistic & Sig. & \\
\hline $\begin{array}{l}\text { Experiment } \\
\text { Control }\end{array}$ & 1.198 & 1.164 & Homogeneous \\
\hline
\end{tabular}

From table 4 it can be seen that, based on the gained mean score, the significant score (sig) of the data is 0.164 , which is higher than 0.05 . Therefore, it can be concluded that the data variance of the post-test of both experimental and control groups is homogeneous.

The last analysis done is hypothesis testing. As previously stated, for hypothesis testing, the research used t-test. The t-test aims at finding out whether or not there is a significant difference in the mean score between the experimental group and the control group. Furthermore, hypothesis testing is also used to find out whether the use of picture cues is effective or not to teach writing to students of grade eight of junior high school. Theoretically, the hypothesis is rejected if the probability (sig.) is higher than 0.05 , which means there is no significant difference between the experimental and control groups. On the contrary, the hypothesis is accepted if probability (sig.) is lower than 0.05 , which means there is a significant difference in both groups. The result of hypothesis testing is presented through table 5 .

Table 5. Independent Sample t-Test

\begin{tabular}{lllll}
\hline Class & N & Df & Sig. (2.tailed) & Decision \\
\hline Experiment & 28 & 54 & 0.000 & Have a \\
Control & 28 & & & Difference \\
\hline
\end{tabular}

(Source: Data analysis SPSS 16) 
Table 5 shows the result of t-test computation of both experimental and control groups, particularly the result of independent t-test of bothgroups in the post-test. From the table it's clear that the final result is 0.000 , which is below 0.05. It means that the proposed hypothesis is accepted and the null hypothesis is rejected. Therefore, it can beconcluded that the use of picture cues is effective to teach writing becausethere's significant difference in writing ability between the students who are taught using picture cues and those taught without picture cues.

Regarding the findings this research shows, it highlights the theory stating that picture cues as media can be stimulus for students during the learning process (Wright, 1989)). Furthermore the research findings also support the notion that when used as learning media, pictures (including picture cues) can best serve as an aid to motivate, demonstrate, and instruct the students during the learning process. It also helps students to be able to understand the material more easily because it presents realistic format that helps students to think and get more ideas in composing a text. In other words, picture cues is just an effective tool to support the students' learning to write in English.

In the research field, there are some supporters to the findings of this study. Among the researches of the same topic, some of the researches which show similar results, that picture (and picture cues) is an effective tool to use in learning writing, are such researches done by Wijayanti (2012), Noor (2014), and Rizkiani (2016) who have researched the effectiveness of pictures and picture series in teaching writing. The researches of these three resulted in the conclusion that pictures is effective to use in learning writing.

Furthermore, there's an interesting fact in regards to the effectiveness of pictures use in the classroom. It's that surprisingly pictures are serving as a great help in a reading class as well. This is what Maulina (2015) proved through her research on the use of pictures in learning reading amongstudents of junior high school. Maulina's research concluded that pictures are effective to improve the students' reading ability.

\section{CONCLUSION}

In conclusion, picture cues is an effective media to use in teaching writing, particularly in writing recount text. It's shown through the outcome this research gains which shows that after being given treatment of picture cues, the students show better improvement than that of those who aren't given picture cues. This fact once again proves that pictures and or picture cues is effective. And there's no doubt about it. However, there's another side of the research fields which is interesting to dig more. It's the issue whether picturecues is also effective to use in teaching other language skills or whether it's alsoeffective to use among students of higher or lower than junior high school level.This is such an intriguing issue worth further researches. 


\section{REFERENCES}

Brown, D. H. 2001.Teaching by Principle. San FransiscoCallifornia: Longman.

Collins. 2005. Collins English Dictionary. Complete and Unabridged.New Edition. Glasgow: HarperCollins Publisher.

Harmer, J. 1998.How to Teach English. Kuala Lumpur: Longman.

Heaton, J. B. 1975. Writing English Language Tests. Kuala Lumpur: Longman.

Maulina, U. 2015. Using Picture Storybook to Improve Students' Reading Ability for the Sixth Grade Students in SD MuhammadiyahTegalayang 1, Pandak, Bantul, Yogyakarta in Academic Year 2014/2015. Yogyakarta: Universitas Ahmad Dahlan.

Noor, F. 2014. Implementing Sequence Picture to Improve Students' Ability in Writing Narrative Text for Grade X of MAN LAB UIN in the Academic Year of 2013/2014. Yogyakarta: UniversitasNegeri Yogyakarta.

Oxfrod. 2015. Oxford Advanced Learner's Dictionary. Oxfrod: Oxford University Press.

Rizkiani, F. 2016.The Effectivenes of Using Picture to Improve Students Writing Skill for Eight Grade Students in the Academic Year 2015/2016. Yogyakarta: Universitas Ahmad Dahlan.

Tedrow, K., Mary. 2018. Write, Think, Learn. Tapping the Power of Daily Student Writing Across the Content Areas. New York: Routledge.

Wijayanti, I. 2012. The Effect of Picture Series on the Writing Ability og Grade Eight Students of SMPNegeri 1 Kalasan, Sleman in the Academic Year 2011/2012. Yogyakarta: UniversitasNegeri Yogyakarta.

Wright. 1989. The Media Represantation of Refuges, Visual Studies. http//dx.doi.org/10.1080/1472568022000005053/was retrieved on Desember 17, 2017 at 20.15 p.m. 